\title{
Design method of the mix ratio of hot mix plant recycled asphalt mixture containing high mixture content
}

\author{
He Yunwu ${ }^{2}$, Liu Tao ${ }^{1}$, Wang Tao ${ }^{1}$, Liang Xiayi ${ }^{1}$, Wei Hanxin ${ }^{1}$, Zheng Zhigang ${ }^{1}$, Xiao Xin ${ }^{3 *}$ \\ ${ }^{1}$ Shenzhen Yuetong Construction Engineering Co., Ltd, 518019, Shenzhen, China \\ ${ }^{2}$ Shenzhen Tagen<group> Co., Ltd, 518034, Shenzhen, China \\ ${ }^{3}$ Foshan University, 528000, Foshan, China
}

\begin{abstract}
This paper mainly used the Superpave and the Marshall design methods to design the mix ratio of the hot mix plant recycled asphalt mixture. The road performance of AC-20, SUP-20 with 30\% RAP content and AC-20 with 50\% RAP content was studied to evaluate the water stability and high temperature stability and low temperature crack resistance of the recycled asphalt mixture. Research shows that the road performance of AC-20 mixed with 50\% RAP content meets the technical requirements of the same type of asphalt mixture. It is recommended to use the Marshall design method for hot mix plant recycled asphalt mixture design.
\end{abstract}

\section{Introduction}

The hot mix in-plant recycling technology is currently the most commonly used pavement recycling technology at home and abroad. At present, the content of reclaimed asphalt mixture (RAP) is mostly controlled at $10 \% \sim 30 \%$ ${ }^{[1-3]}$. With the rapid development of highway construction in China, many asphalt concrete pavements are in the period of medium and overhaul, and the waste asphalt mixture produced is increasing year by year ${ }^{[4,5]}$. Therefore, how to increase the proportion of RAP in recycled asphalt mixtures under the premise of meeting performance requirements is an important subject that scholars continue to explore. However, there are also many difficulties in the research process. For instance, compared with conventional hot mix asphalt mixtures, there are more variables involved in the design of recycled asphalt mixtures, and the content of new asphalt, new aggregates, RAP and the recycling agent should be taken into consideration. The conventional hot mix asphalt mixture design method has been unable to meet the needs of the mix design ${ }^{[6,7]}$. Therefore, it is of great significance to develop the optimization design of the mix ratio of the large content hot mix recycled asphalt mixture at a central plant.

\section{Design specifications}

This paper mainly used Superpave design method and Marshall design method to design the mix ratio of the hot mix plant recycled asphalt mixture. The content of this section mainly highlighted the selection of design indicators and the study of design methods. At the same time, on the basis of raw material tests, two design methods were used to design the mix ratio for AC-20 and SUP-20 with different reclaimed asphalt mixtures. The results were compared for analysis.

Existing studies have shown that new asphalt has a reconciling effect on the reclaimed asphalt and can reduce the viscosity of the reclaimed asphalt. However, as the content amount of reclaimed asphalt added to the recycled asphalt mixture increases, the new asphalt may not be able to blend the recycled asphalt that meets the requirements of use. Considering the performance of the asphalt mixture, the content of reclaimed asphalt should not exceed $30 \%$. When the amount exceeds this range, a suitable recycling agent should be selected to further restore the performance of the aged asphalt in the milling material. The selected recycling agent should be able to supplement the missing components of the reclaimed asphalt and feature good compatibility with the reclaimed asphalt. This project adopted self-developed SBS modified asphalt recycling agent to improve the performance of the reclaimed asphalt

The key technical indexes of recycled asphalt are softening point, ductility, permeability and viscosity. All of these indicators must meet the Technical Specification for Asphalt Pavements on Highway (F40- (2004)). The details are shown in Table 1.

Table 1 Specification requirements for recycled asphalt (SBS modified asphalt)

\begin{tabular}{|c|c|c|c|c|}
\hline Item & $\begin{array}{c}\text { Penetration } \\
25^{\circ} \mathrm{C}, 0.1 \mathrm{~mm}\end{array}$ & $\begin{array}{c}\text { Softening } \\
\text { point }{ }^{\circ} \mathrm{C}\end{array}$ & $\begin{array}{c}\text { Ductility } \\
\left(10^{\circ} \mathrm{C}\right), \\
\mathrm{cm}\end{array}$ & $\begin{array}{c}135^{\circ} \mathrm{C} \\
\text { kinematic } \\
\text { viscosity, } \\
\text { Pa.s }\end{array}$ \\
\hline $\begin{array}{c}\text { Recycled } \\
\text { asphalt }\end{array}$ & $30-60$ & $\geq 60$ & $\geq 20$ & $\leq 3$ \\
\hline
\end{tabular}

In order to ensure the performance of the recycled asphalt mixture so that it cannot be lower than the

*Corresponding author: 604849392@qq.com 
technical standard of conventional asphalt pavement, the design of the hot mix plant recycled asphalt mixture must meet the "Technical Specification for Construction of Highway Asphalt Pavements" (F40-2004), especially the volume and the performance standards. The details are shown in Table 2 and Table 3.

Table 2 Design specification requirements of AC-type hot mix in-plant recycled modified asphalt mixture

\begin{tabular}{|c|c|}
\hline Testing item & AC-20 \\
\hline Striking times & 75times per side \\
\hline Stability (kN) no less than & 8.0 \\
\hline FL (0.1mm) & $20 \sim 40$ \\
\hline VA (\%) & $4.0 \sim 6.0$ \\
\hline Voids filled with asphalt (\%) & $65 \sim 75$ \\
\hline \begin{tabular}{c} 
Residual stability (\%) not less than \\
\hline $\begin{array}{c}\text { Freeze-thaw split strength ratio (\%) } \\
\text { not less than }\end{array}$
\end{tabular} & 85 \\
\hline $\begin{array}{c}\text { Dynamic stability (number of } \\
\text { times/mm) not less than }\end{array}$ & 2800 \\
\hline
\end{tabular}

Note: 1. Conditional on the air void of the Marshall test pieces designed to be $3 \%, 4 \%, 5 \%$ and $6 \%$, the voids in the mineral aggregate (VMA, \%) of AC-25 mixture is 11 , $12,13,14$, respectively. When the design air void is less than an integer, use the interpolation method to determine the minimum VMA required. 2. Conditional on the air void of the Marshall test pieces designed to be $4 \%, 5 \%$ and $6 \%$, the voids in the mineral aggregate (VMA, \%) OF AC20 mixture is $13,14,15$ respectively. If the design air void is not an integer, use the interpolation method to determine the minimum VMA required.

Table 3 Design specification requirements for SUP-type hot mix plant recycled asphalt mixture

\begin{tabular}{|c|c|}
\hline Testing item & SUP20 \\
\hline $\begin{array}{c}\text { Compaction through rotation (number } \\
\text { of rotation) }\end{array}$ & 100 \\
\hline $\begin{array}{c}\text { Degree of compaction per design time } \\
(\%)\end{array}$ & $\leq 89$ \\
\hline $\begin{array}{c}\text { Degree of compaction in the } \\
\text { beginning (\%) }\end{array}$ & $\leq 98$ \\
\hline $\begin{array}{c}\text { Degree of compaction of the end (\%) } \\
\text { VMA (\%) }\end{array}$ & $65 \sim 75$ \\
\hline VFA (\%) & $0.6 \sim 1.2$ \\
\hline $\begin{array}{c}\text { Filler-asphalt ratio (\%) } \\
\text { Freeze-thaw split strength ratio (\%) no } \\
\text { less than }\end{array}$ & 80 \\
\hline $\begin{array}{c}\text { Dynamic stability (number of } \\
\text { times/mm) no less than }\end{array}$ & 2800 \\
\hline
\end{tabular}

\section{Design method}

When it comes to the design method of the mix ratio of the hot mix in-plant recycled asphalt mixture, representative reclaimed asphalt mixture specimens need to be selected with corresponding properties identified. Also the aggregate gradation, asphalt content and asphalt viscosity at $60^{\circ} \mathrm{C}$ of the reclaimed asphalt mixture should be determined. In the meantime, the angularity of coarse and fine aggregates should be checked and new or reclaimed aggregates of proper particle sizes should be added to adjust the gradation defects. The AASHTO T202 method or T0625-2000 specified method can be used to test the viscosity of asphalt at $60^{\circ} \mathrm{C}$, and based on which the content and grade of the fresh asphalt in the recycled asphalt mixture is determined. Or the content and grade of the fresh asphalt can be determined by testing the penetration of the reclaimed asphalt at $25^{\circ} \mathrm{C}$.

\section{Raw material test}

This paper used diorite as the aggregate and SBS modified asphalt as the asphalt. The properties of raw materials are shown in Table 4-7:

Table 4 Aggregate density test results

\begin{tabular}{|c|c|c|c|c|}
\hline $\begin{array}{c}\text { Material } \\
\text { particle } \\
\text { size } \\
(\mathrm{mm})\end{array}$ & $\begin{array}{c}\text { Apparent } \\
\text { relative } \\
\text { density } \\
\left(\mathrm{g} / \mathrm{cm}^{3}\right)\end{array}$ & $\begin{array}{c}\text { Surface- } \\
\text { dry } \\
\text { relative } \\
\text { density } \\
\left(\mathrm{g} / \mathrm{cm}^{3}\right)\end{array}$ & $\begin{array}{c}\text { Bulk } \\
\text { volume } \\
\text { density } \\
\left(\mathrm{g} / \mathrm{cm}^{3}\right)\end{array}$ & $\begin{array}{c}\text { Water } \\
\text { absorption } \\
(\%)\end{array}$ \\
\hline 19 & 2.929 & 2.913 & 2.905 & 0.273 \\
\hline 16 & 2.931 & 2.916 & 2.908 & 0.277 \\
\hline 13.2 & 2.934 & 2.918 & 2.909 & 0.293 \\
\hline 9.5 & 2.942 & 2.916 & 2.903 & 0.447 \\
\hline 4.75 & 2.937 & 2.905 & 2.888 & 0.586 \\
\hline 2.36 & 2.921 & 2.865 & 2.836 & 1.025 \\
\hline 1.18 & 2.913 & $/$ & $/$ & $/$ \\
\hline 0.6 & 2.910 & $/$ & $/$ & $/$ \\
\hline 0.3 & 2.900 & $/$ & $/$ & $/$ \\
\hline 0.15 & 2.896 & $/$ & $/$ & $/$ \\
\hline 0.075 & 2.896 & $/$ & $/$ & $/$ \\
\hline $\begin{array}{c}\text { Mineral } \\
\text { powder }\end{array}$ & 2.763 & $/$ & $/$ & $/$ \\
\hline
\end{tabular}

Table 5 Asphalt density test results

\begin{tabular}{|c|c|}
\hline Asphalt Type & Density $\left(\mathrm{g} / \mathrm{cm}^{3}\right)$ \\
\hline SBS modified asphalt & 1.040 \\
\hline
\end{tabular}


Table 6 Asphalt mixture extracting test results

\begin{tabular}{|c|c|c|c|c|c|c|c|c|c|c|c|c|}
\hline & \multirow{2}{*}{$\begin{array}{l}\text { Asphalt - } \\
\text { aggregate } \\
\text { ratio (\%) }\end{array}$} & \multicolumn{7}{|c|}{ The pass rate of the following sieve pore $(\%)$} & \multicolumn{4}{|c|}{ (square hole sieve) } \\
\hline & & 26.5 & 19.0 & 13.2 & 9.5 & 4.75 & 2.36 & 1.18 & 0.6 & 0.3 & 0.15 & 0.075 \\
\hline Coarse RAP & 2.1 & 100 & 98.2 & 91.8 & 76.8 & 24.8 & 10.1 & 8.5 & 7.1 & 5.4 & 3.8 & 3.1 \\
\hline Fine RAP & 5.8 & 100 & 100 & 100 & 99.9 & 78.8 & 63.6 & 50.1 & 45.7 & 28.6 & 17.9 & 12.8 \\
\hline
\end{tabular}

Table 7 Coarse and fine RAP aggregates improved density after extraction test results

\begin{tabular}{|c|c|c|c|c|}
\hline \multirow{2}{*}{$\begin{array}{c}\text { Material } \\
\text { specification }\end{array}$} & \multicolumn{2}{|c|}{ Coarse RAP } & \multicolumn{2}{c|}{ Fine RAP } \\
\cline { 2 - 5 } & $\geq 4.75 \mathrm{~mm}$ & $<4.75 \mathrm{~mm}$ & $\geq 4.75 \mathrm{~mm}$ & $<4.75 \mathrm{~mm}$ \\
\hline $\begin{array}{c}\text { Coarse and fine } \\
\text { aggregate } \%\end{array}$ & 75.3 & 24.7 & 15.9 & 84.1 \\
\hline $\begin{array}{c}\text { Bulk volume } \\
\text { density } \\
\left(\mathrm{g} / \mathrm{cm}^{3}\right)\end{array}$ & 2.922 & 2.908 & 2.720 & 2.726 \\
\hline
\end{tabular}

\section{Asphalt mixture mix ratio design}

\subsection{AC-20 asphalt mixture gradation design $(30 \%$ RAP)}

The RAP content is $30 \%$. According to the existing asphalt mixture mix ratio design method and process, the synthetic gradation is determined through the selection and testing of different gradations and contents of asphalt. As shown in Table 8 , the best asphalt-aggregate ratio is determined as $4.4 \%$. And the volume properties of the mixture are shown in Table 9.

Table 8 Designed gradation of AC-20 asphalt mixture

\begin{tabular}{|l|l|l|l|l|l|l|l|l|l|l|l|l|}
\hline \multirow{2}{*}{ Gradation type } & \multicolumn{8}{|c|}{ Quality performance (\%) through the following sieve pores (square hole sieve, $\mathrm{mm})(\%)$} \\
\cline { 2 - 12 } & 26.5 & 19.0 & 16.0 & 13.2 & 9.5 & 4.75 & 2.36 & 1.18 & 0.6 & 0.3 & 0.15 & 0.075 \\
\hline $\begin{array}{l}\text { Designed } \\
\text { gradation }\end{array}$ & 100 & 95.2 & 89.8 & 76.5 & 60.2 & 44.8 & 26.5 & 19.4 & 15.2 & 10.1 & 7.6 & 4.7 \\
\hline
\end{tabular}

Table 9 Asphalt mixture volume properties

\begin{tabular}{|c|c|c|}
\hline $\begin{array}{c}\text { Properties of the } \\
\text { asphalt mixture }\end{array}$ & Designed results & $\begin{array}{c}\text { Technical } \\
\text { requirements }\end{array}$ \\
\hline VA $(\%)$ & 4.56 & $4.0 \sim 6.0$ \\
\hline VMA $(\%)$ & 13.64 & $\geq 13.48$ \\
\hline VFA $(\%)$ & 67.23 & $65 \sim 75$ \\
\hline MS(kN) & 16.25 & $\geq 8$ \\
\hline FL $(0.1 \mathrm{~mm})$ & 27.3 & $15 \sim 40$ \\
\hline
\end{tabular}

Conditional on the best asphalt-aggregate ratio, the water damage resistance of the asphalt mixture was tested through the water immersion Marshall test and the freezethaw splitting test. At the same time, the rutting test and the low-temperature tests were carried out. The performance test results are shown in Table 10.
Table 10 Performance test results of AC-20 asphalt mixture

\begin{tabular}{|c|c|c|c|c|}
\hline Test name & $\begin{array}{c}\text { Water } \\
\text { immersion } \\
\text { Marshall } \\
\text { test }\end{array}$ & $\begin{array}{c}\text { Freeze- } \\
\text { thaw } \\
\text { splitting } \\
\text { test }\end{array}$ & $\begin{array}{c}\text { Rutting } \\
\text { test }\end{array}$ & $\begin{array}{c}\text { Low- } \\
\text { temperat } \\
\text { ure } \\
\text { bending } \\
\text { test }\end{array}$ \\
\hline $\begin{array}{c}\text { Test } \\
\text { specification }\end{array}$ & $\begin{array}{c}\text { Marshall } \\
\text { residual } \\
\text { stability } \mathrm{S}_{0} \\
\quad(\%)\end{array}$ & $\begin{array}{l}\text { TSR } \\
(\%)\end{array}$ & $\begin{array}{c}\text { Dynamic } \\
\text { stability } \\
\text { (numbe } \\
\text { r of } \\
\text { times/m } \\
\text { m) }\end{array}$ & $\begin{array}{c}\text { Failure } \\
\text { strain } \\
(\mu \varepsilon)\end{array}$ \\
\hline Test result & 90.2 & 85.8 & 4905 & 2763.0 \\
\hline $\begin{array}{c}\text { Requirement } \\
(\%)\end{array}$ & $\geq 85$ & $\geq 80$ & $\geq 2800$ & $\geq 2500$ \\
\hline
\end{tabular}

It can be seen from Table 10 that the water stability, high temperature stability and low temperature crack resistance of the mixture all meet the requirements of the specification.

\subsection{SUP20 asphalt mixture mix ratio design $(30 \%$ RAP)}

The RAP content is $30 \%$. According to the indoor test, the determined design gradation of the asphalt mixture is shown in Table 11, and the results of the volume properties 
of the mixture are shown in Table 12.

Table 11 SUP-20 Asphalt mixture designed gradation

\begin{tabular}{|l|l|l|l|l|l|l|l|l|l|l|l|l|}
\hline \multirow{2}{*}{ Gradation type } & \multicolumn{8}{|c|}{ Quality performance (\%) through the following sieve pores (square hole sieve, $\mathrm{mm}$ ) (\%) } \\
\cline { 2 - 13 } & 26.5 & 19.0 & 13.2 & 9.5 & 4.75 & 2.36 & 1.18 & 0.6 & 0.3 & 0.15 & 0.075 \\
\hline $\begin{array}{l}\text { Designed } \\
\text { gradation }\end{array}$ & 100 & 94.3 & 75.1 & 51.7 & 42.1 & 25.3 & 20.1 & 16.2 & 9.6 & 8.5 & 4.6 \\
\hline
\end{tabular}

Table 12 SUP-20 asphalt mixture volume properties

\begin{tabular}{|l|l|l|}
\hline $\begin{array}{l}\text { Properties of the asphalt } \\
\text { mixture }\end{array}$ & $\begin{array}{l}\text { Design } \\
\text { performance }\end{array}$ & $\begin{array}{l}\text { Superpave } \\
\text { standards }\end{array}$ \\
\hline Air void VA (\%) & 3.98 & 4.0 \\
\hline VMA(\%) & 15.02 & $\geq 13$ \\
\hline VFA(\%) & 70.89 & $65 \sim 75$ \\
\hline Filler-asphalt ratio (\%) & 1.35 & $0.6 \sim 1.2^{*}$ \\
\hline $\begin{array}{l}\text { Degree of compaction in } \\
\text { the beginning (\%) }\end{array}$ & 83.9 & $\leq 89$ \\
\hline $\begin{array}{l}\text { Degree of compaction of } \\
\text { the end (\%) }\end{array}$ & 97.5 & $\leq 98$ \\
\hline
\end{tabular}

Note: * means that when the coarse gradation is adopted, the filler-asphalt ratio can be increased to 0.8-1.6.

The gradation of this design is under the condition of the best asphalt-aggregate ratio. The water immersion Marshall test and the AASHTO T283 test were carried out to check the water damage resistance of the asphalt mixture. The rutting test and the low temperature tests were carried out at the same time. The test results are shown in Table 13.

Table 13 Performance test results of SUP-20 asphalt mixture

\begin{tabular}{|l|l|l|l|l|}
\hline Test name & $\begin{array}{l}\text { Water } \\
\text { immersion } \\
\text { Marshall } \\
\text { test }\end{array}$ & $\begin{array}{l}\text { Freeze- } \\
\text { thaw } \\
\text { splitting } \\
\text { test }\end{array}$ & Rutting test & $\begin{array}{l}\text { Beam } \\
\text { bending } \\
\text { test }\end{array}$ \\
\hline $\begin{array}{l}\text { Test } \\
\text { specifications }\end{array}$ & $\begin{array}{l}\text { Marshall } \\
\text { residual } \\
\text { stability } \mathrm{S}_{0} \\
(\%)\end{array}$ & $\begin{array}{l}\text { TSR } \\
(\%)\end{array}$ & $\begin{array}{l}\text { Dynamic } \\
\text { stability } \\
(\text { number } \\
\text { of } \\
\text { times } / \mathrm{mm})\end{array}$ & $\begin{array}{l}\text { Failure } \\
\text { strain } \\
(\mu \varepsilon)\end{array}$ \\
\hline \begin{tabular}{l} 
Test result \\
\hline $\begin{array}{l}\text { Requiremen } \\
(\%)\end{array}$
\end{tabular} & 89.5 & 85.7 & 4134 & 2668.0 \\
\hline
\end{tabular}

It can be seen from Table 13 that the water stability, high temperature stability and low temperature crack resistance of the mixture all meet the specification requirements.

The performance of the asphalt mixture designed by the Surperpave design method and the Marshall design method all meets the specification requirements, and the performance of the AC-20 asphalt mixture designed by the
Marshall design method is slightly better than that of SUP20. With overall consideration, this paper recommends the use of Marshall design method for the design of hot mix in-plant recycled asphalt mixture.

\subsection{AC-20 asphalt mixture gradation design (50\% RAP)}

When the use of RAP content is large, it is advisable to add a recycling agent during the design of the hot mix inplant recycled asphalt mix ratio to restore the aged asphalt performance to a proper level to maximize the use of the reclaimed asphalt mixture so that the recycled HMA mixture has the best durability, ensuring that there is sufficient asphalt to coat the blank aggregate, and providing sufficient asphalt to meet the asphalt mixture design needs.

The RAP content used in this design is $50 \%$, and the recycling agent SBS content is $5.8 \%$. The mix ratio design referred to the deisgn of recycled asphalt mixture with $30 \%$ RAP to determine the overall binding material content after the recycling agent is added. The results of the volume properties of the mixture are shown in Table 14.

Table 14 Volume Properties of Asphalt Mixture

\begin{tabular}{|c|c|c|}
\hline $\begin{array}{c}\text { Properties of the } \\
\text { mixture }\end{array}$ & $\begin{array}{c}\text { Design } \\
\text { performance }\end{array}$ & $\begin{array}{c}\text { Technical } \\
\text { requirements }\end{array}$ \\
\hline VA $(\%)$ & 4.63 & $4.0 \sim 6.0$ \\
\hline VMA $(\%)$ & 14.38 & $\geq 13.48$ \\
\hline VFA $(\%)$ & 68.15 & $65 \sim 75$ \\
\hline MS(kN) & 15.78 & $\geq 8$ \\
\hline $\operatorname{FL}(0.1 \mathrm{~mm})$ & 26.1 & $15 \sim 40$ \\
\hline
\end{tabular}

The water immersion Marshall test, freeze-thaw splitting test, high temperature rutting and low temperature test were carried out. The performance test results are shown in Table 15. 
Table 15 Performance test results of AC-20 asphalt mixture

\begin{tabular}{|l|l|l|l|l|}
\hline Test name & $\begin{array}{l}\text { Water } \\
\text { immersion } \\
\text { Marshall } \\
\text { test }\end{array}$ & $\begin{array}{l}\text { Freeze- } \\
\text { thaw } \\
\text { splitting } \\
\text { test }\end{array}$ & $\begin{array}{l}\text { Rutting } \\
\text { test }\end{array}$ & $\begin{array}{l}\text { Beam } \\
\text { bending } \\
\text { test }\end{array}$ \\
\hline $\begin{array}{l}\text { Test } \\
\text { specifications }\end{array}$ & $\begin{array}{l}\text { Marshall } \\
\text { residual } \\
\text { stability } \mathrm{S}_{0} \\
(\%)\end{array}$ & TSR $(\%)$ & $\begin{array}{l}\text { Dynamic } \\
\text { stability } \\
(\text { number } \\
\text { of } \\
\text { times } / \mathrm{mm})\end{array}$ & $\begin{array}{l}\text { Failure } \\
\text { strain } \\
(\mu \varepsilon)\end{array}$ \\
\hline Test result & 88.6 & 85.1 & 4534 & 2675.0 \\
\hline $\begin{array}{l}\text { Requirement } \\
(\%)\end{array}$ & $\geq 85$ & $\geq 80$ & $\geq 2800$ & $\geq 2500$ \\
\hline
\end{tabular}

It can be seen from Table 15 that the water stability, high temperature stability and low temperature crack resistance of the mixture all meet the requirements of the specifications. The performance is equivalent to that of asphalt mixture with $30 \%$ RAP, indicating that the modified SBS recycling agent can effectively improve the performance of the reclaimed asphalt mixture.

\section{Conclusion}

This paper used the Superpave design method and the Marshall design method to design the mix ratio of hot mix in-plant recycled asphalt with high RAP content. The research conclusions are as follows:

(1) The water stability, high temperature stability and low temperature crack resistance of AC-20 and SUP20 with $30 \%$ RAP were studied, and all the indicators meet the specification requirements, and the performance of the AC-20 asphalt mixture designed by Marshall design method is better than that of SUP20.

(2) The Marshall design method is recommended for the design of hot mix in-plant recycled asphalt mixture.

(3) The performance of AC-20 recycled asphalt mixture with high RAP content (50\%) was analyzed. All performance indicators can also meet the technical requirements of asphalt mixture of the same type.

\section{References}

1. LAN Qing, XU Wei, ZHAO Jingsong, et al.Study and Evaluating the Test Sections of High Percentage RAP in Hot Recycled Asphalt Pavement in Guanghui Freeway[J]. Highway Engineering, 2013, 38(4):7983.2.

2. WU Gesen, LI Yuhong, SI TU Lixin, et al. Research on the Mix Ratio Design of Hot Mix Plant Recycled Mixture with High RAP content [J]. Highway, 2014, 10:251-254.

3. CAI Ziqian. Performance Research of Hot Recycled Asphalt Mixtures with High Percentages of Reclained Asphalt Pavement[D]. Chongqing: ChongQing Jiaotong University, 2017.

4. YANG Cheng. Effects of RAP Content on Performance of Reclaimed Asphalt and Reclaimed Asphalt Mixture [J]. Highway Engineering, 2016, 41 (6): 299-302.
5. FANG Yang, LIU Yu, ZHANG Guomin. Research on the High Temperature Stability Performance of Hot Mix Plant Recycled Mixture with High RAP Content [J]. Highway, 2013 (4): 99-102.

6. Shirodkar P, Mehta Y, Nolan A, et al. A Study to Determine the Degree of Partial Blending of

7. Reclaimed Asphalt Pavement (RAP) Binder for High RAP Hot Mix Asphalt. 2011, 25(1): 150-155.

8. SHI Biao, JI Jie, CAO Dongwei. Research on the Performance of Hot Recycled Asphalt Mixture with High Mix ratio [J]. Highway, 2013, 9:205-208. 